\title{
Evaluation of Community Health Center Management Information System (SIMPUS), Primary Care (P Care), and Bridging Data System in Sukoharjo District
}

\author{
Agung Kurniawan'), DidikTamtomo²), Bhisma Murti1) \\ 1)Masters Program in Public Health, Universitas Sebelas Maret \\ 2)Faculty of Medicine, Universitas Sebelas Maret
}

\begin{abstract}
Background: Community health center (puskesmas)management information system or often referred to as SIMPUS is a local health system aimed at providing health information at primary health care level. P Care (Primary Care) application is an information system that is designed to serve BPJS patients. The bridging system links SIMPUS with $\mathrm{P}$ care application. These three systems have been used in all puskesmas in Sukoharjo district since 2017. This study aimed to evaluate the implementation of community health center management information system (Simpus), Primary Care (P Care), and bridging data system, in Sukoharjo District, Central Java.

Subjectsand Method: This was a qualitative study. The study was conducted in Sukoharjo, Kartasura, Bendosari, Mojolaban community health centers, in Sukoharjo District, Central Java, from October to December, 2017. Four community health centers were selected randomly from 13 community health centers in Sukoharjo. The dependent variables were information service, performance, efficiency, and security. The independent variable was health information system (SIMPUS, P care, and bridging system). The data were collected by in-depth interview, direct observation, and document review. Data credibility was checked by a triangulation method.

Results: Three health information systems (SIMPUS, P care, and bridging system) have been implemented in Sukoharjo District. However, their performance is yet to be improved. Loading time was lengthy and error often occurred. Patients often complained of the lengthy service. Some items in the information system form were left blank. Data entry occasionally was inconsistent with examination outcome. The security system of the health information existed, but sometimes unauthorized individuals can access and use that information. There was a lack of human resources and hardware. The health information system had not met the information need.

Conclusion: Three health information systems (SIMPUS, P care, and bridging system) have been implemented in Sukoharjo District. However, their performance is yet to be improved. Some obstacles have yet to be resolved.
\end{abstract}

Keywords: evaluation, SIMPUS, P care application, bridging system

\section{Correspondence:}

Agung Kurniawan. Masters Program of Public Health, Jl. Ir. Sutami No. 36A Surakarta 57126, Jawa Tengah. E-mail: agungkurniawan991@gmail.com. Mobile: +6285257292206.

\section{BACKGROUND}

Obtaining proper health services is the right of citizens of Indonesia in accordance with those contained in the Constitution of 1945 article $28 \mathrm{H}$ verse 1 which saysthat every person has the right to live a prosperous and spiritual life, to live and get a good and healthy environment. With the implementtation of BPJS health starting in 2014 is very helpful to the people of Indonesia to be able to get health insurance at health facilities.

Based on the data from health ministry financing and health ministry the number of participants in 2017 who have registered to become BPJS Health participants have increased from 2014, 2015, and 2016. In 2014, the number of regis- 
tered participants was $13,423,653$ participants, by 2015 the number of registered participants was $156,790,287$, and by 2016 the number of registered participants was $171,677,176$. It was also followed by the increase of First Level Health Facility (FKTP) which cooperated with JKN (BPJS Kesehatan), proven in the year of 2014, there were 18,437 FKTP who have cooperated with JKN (BPJS Health), in 2015 there were 19,969 FKTP which have been working with JKN (BPJS Kesehatan), and in 2016 there were about 80,708 FKTP who have worked with JKN (BPJS Health). By the increaseof the number of participants BPJS, it certainly neededan information system that can support services in a health facility, so that in 2014 BPJS issued an information system called $\mathrm{P}$ care application for the level of the public health center.

Public Health Centers in Sukoharjo areas have been using $\mathrm{P}$ care application since 2014 and using SIMPUS since 2012. At that time, between $\mathrm{P}$ care and SIMPUS applications are still stand-alone so that officers must input patients' data in 2 different information systems. Public Health Centers in Sukoharjo District in 2017 established a system called Bridging system. According to BPJS Official Media Media (2014) Bridging System is the use of web-based application service that can connect health service systems into one, which is intended to be able to improve health services in hospitals or health centers, and other health services that receive JKN services. Officers simply input in SIMPUS and will automatically log in the $\mathrm{P}$ care application database. Based on preliminary study results that researchers have done there are some problems that arise during the use of these three information systems such as during the use of these three systems have not been conducted evaluation of the related system that already running, public health centers officers in the region Sukoharjo in input data to SIMPUS there is still an incomplete or unfilled, and the P Care application is often error so that it can also hamper the performance of SIMPUS.

This study aims to evaluate SIMPUS and $\mathrm{P}$ Care application in the presence of Bridging System in Public Health Center Sukoharjo District.

\section{SUBJECTS AND METHOD}

This was a descriptive qualitative study. The study was conducted to describe and analyzed the implementation of SIMPUS, P care application, and bridging system.

The study was conducted in Sukoharjo District and took place at Sukoharjo, Kartasura, Bendosari, Mojolaban, Sukoharjo Public Health Center, and BPJS Office. The data collection process was conducted from October to December 2017.

Informants in this study were the registration officer, admin reporter, pharmacy, and nurse midwife.

The number of samples used in this study was four public health centers with calculation according to (Wariyanti et al., 2016) presented as follows:

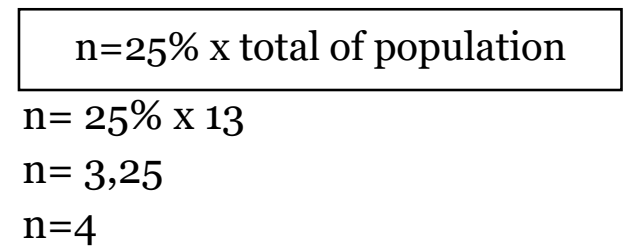

Ket: $n=$ total of samples

The sampling technique used a purposive sampling technique. The sampling technique is based on the following criteria: 1. The largest number of patient visits at the Sukoharjo District Health Center.

2. Have run or implemented Public health centers Management Information System, P Care application, and Bridging System. 
Journal of Health Policy and Management (2017), 2(2): 157-164

https://doi.org/10.26911/thejhpm.2017.02.02.07

The techniques used by the researcher were the in-depth interview, observation, and documentation study. Data collection instruments during the study were interview guides, observation, and documenttation studies.

Data analysis techniques in this study included data reduction, data presentation, and conclusion.

Validation used in this research was source triangulation and technique. Triangulation of the source of the researchers compared the results of interviews of registration officers, reporters, nurses, and Pharmacies, with the results of interviews with the head of IT Sukoharjo City Health Office and BPJS Health Surakarta IT. Triangulation techniques researchers compared the results of interviews with the results of observation.

\section{RESULTS \\ 1. The Performance of Public Health Centers Management Information System and $\mathbf{P}$ Care Application with Data Integration System at PHC}

Based on the results of the study that has been done to 4 public health centers in Sukoharjo area shows that the existing information system in public health center sukoharjo were still often long loading and error. This was proven by the results of interviews that showedthat there were 14 informants stated that there was often a long process. There was an informant stating that there was no old application process work. An informant said that there was no error in the information system.

2. Information Generated PHC Management Information System and $P$ Care application with the Data Integration System at PHC

Based on the results of the study, it was found out that there were still data that were not inputted in the items of information systems, there were data that have been inputted but not stored, and there were data inputted in the information system which were not relevant to the results of the examination. It can be proven by interview result indicating that there were 10 informants stating that there were some data which were not filled in computer, 8 respondents stated that there were data that have been in input but not stored, there were 8 informants stating that the data inputted were less relevant to current condition or inspection results.

\section{Control of PHC Management} Information System and Application of $P$ Care System Data Integration at PHC

Based on the results of the study, it was found out that there were security systems installed in computers and information systems so that computers and information systems cannot be attacked by viruses, hackers, and cannot be accessed by unauthorized parties, but in fact, there were unauthorized officers who can access and open and use the information systems.

This was proven by the results of interviews showing that there were 9 informants who stated that there were other parties other than authorized officers who can access and use SIMPUS and P care in each section. All PHC in Sukoharjo area already have a security system in the information system.

4. The EfficienceUse of PHC Management Information System and $P$ Care System Data Integration application at PHC

Based on the results of the study, it was found out that the number of human resources, hardware, and information systems have not been in accordance with the needs. Officers still frequently did the same data input repeatedly. The results of 
interviews with 9 informants showed that the number of human resources, hardware, and information systems have not been in accordance with the needs. A total of 5 informants said that the officers inputted the data repeatedly.

\section{Services Provided by PHC Mana- gement Information System and $P$ Care System Data Intensification Application at PHC}

Based on the results of the study, it was found out that there were patients who complained related to services at the PHC and that the information systems were difficult to use so that it caused the queue of patients. The results of interviews on 14 informants stated that there were patients complaining about services at PHC, and 11 informants said that the information system was difficult to use so that the patients had to queue.

\section{DISCUSSIONS}

1. Management Information System of Community Health Center (Puskesmas) and $P$ Care Application with Bridging Data System at Puskesmas

There were 14 informants who stated that existing information systems in Puskesmas often occur long loading and error, this is due to the capacity of the internet in sukoharjo district health centers which uses the standard capacity of the Internet for an information system.But there are some officers who do not use the internet properly, such as youtube streaming, downloading files, and using for smartphones. These activities can reduce the bandwidth of the internet itself and it reduced the speed of an information system work, and $\mathrm{P}$ care application which is offline at certain times, thus inhibiting the bridging system andmaking the officers to work harder because they have to input the data in Pcare application after it is online

It is not in accordance with Ministry of Health of 2011 about hospital information system which states that one of the SIMPUS purposes is to help the administration and management of puskesmas in storing and transmitting data for the report preparation about health condition in each Puskesmas.

2. The Information from Management Information System of Puskesmas and $P$ Care Application with Bridging Data System at Puskesmas

There were 10 informants (66.67\%)who stated that there are some data which are not filled in the computer, it is because the data in the medical record which is the main source is incomplete, the number of officers are limited while there are enormous number of patients and works so that officers only fill certain items.The officers' understanding about information system "the important thing is the data in $\mathrm{P}$ care is complete, it does not matter if the data in SIMPUS is incomplete", there was no warning in SIMPUS for the officer to complete the item in the information system before it is saved, and most of the officers have not received a training about the data that must be inputted in the information system.

This is not in accordance with Loudon (2007) and Kristanto (2007) who characterized the quality information such as accuracy, relevance, timeliness, completeness, economical, efficiency, and reliability.

There were 8 informants who stated that there are some data that have been input but they are not stored. This is due to the problem in Internet network, there is a network disruption in the storage process. The interference causes the problem in storaging the input data. 
Journal of Health Policy and Management (2017), 2(2): 157-164

https://doi.org/10.26911/thejhpm.2017.02.02.07

This is not in accordance with the results of a study by Krishnan et al. (2010) which stated that there are several advantages in using health management information systems such as effectiveness, efficiency, resource saving, flexible frameworks, save officers' times in recording and reporting, and it can be recovered within two years if the system is fully operated.

There are 8 informants who stated that data inputted is less relevant to the current condition. This is because the data in the medical record is not complete, therefore, when the officer input the data into the computer, the data is not in accordance with the checkup results.

This is not in accordance with the Ministry of Health of 2011 about hospital information system which stated that one of the SIMPUS purposes is to provide up to date information which is accurate and correct about health conditions in a health center.This is also not in accordance with Loudon (2007) and Kristanto (2007) which stated that one of the characteristics of quality information is relevance, the information is in accordance with the needs and associated with the problems encountered.

\section{The Control of Puskesmas Mana-} gement Information System and $P$ Care Application with Bridging Data System at Puskesmas

All computers and information systems that exist in Sukoharjo Puskesmas have installed security tools in the form of username and password that must be filled by the officer before entering and accessing the data and information. However, there were 9 informants who stated that in addition to the authorized officers who were able to access and use SIMPUS and P care in each section, each username and password in each unit is known by most of the officers who do not have rights to enter and access the information in the unit's information system, this is because there are some officers who often help a unit, and in the end the officer will know the username and password of the unit. This is not in accordance with Jogiyanto (2005) who stated that the purpose of restricting access is to prevent unauthorized personnel to access the data. The access must be restricted to unauthorized persons, which can be by physical isolation, authorization and identification and restriction of usage.

4. The Efficient Use of Puskesmas

Management Information System and $P$ Care Application with Bridging Data System at Puskesmas

According to (Krishnan et al., 2010), there are several advantages in using health management information systems such as improving effectiveness, efficiency, saving resources, flexible frameworks, saving officers' time in recording and reporting, and can be recovered within two years if the system is fully operated.

\section{Services provided by Puskesmas Management Information System (SIMPUS) and $P$ CareApplication with Bridging Data System at Pus- kesmas}

There were 14 informants who stated that there are some patients who complain about the services provided by Puskesmas.This is due to the errors in $\mathrm{P}$ care application information system and the process of the application took a very long time so that it obstructed the patients services. The problem that often happens is the complaints from patients because the referral service takes a long time, it is also due to offline $\mathrm{P}$ care application while the reference letter number is in the $\mathrm{P}$ care application.

This is not in accordance with the result of a study by Arifin et al., (2013), it is stated that service reliability includes rapid and appropriate patient admissions proce- 
dures, service procedures that ease the patients to get the services, fast and on time service, and officers who provide error-free service.

There were 11 informants who said that the information system is difficult to use so that the patient have to wait in line. This is because the error system and the application process work that takes a long time so it takes longer time to serve the patient. This is one of the causes of queues and complaints from patients, because some of the officers did not do training related to the use of information systems, therefore, some officers do not really understand about the usage procedures.

This is not in accordance with the results of a study by Ramdhani (2014) which stated that one of the benefits of the management information system is to improve the ease of accessing data accurately by the data users without any intermediaries from other information systems.

Based on the results of this study, it can be concluded:

1. The errors and long loading in Puskesmas Management Information System (SIMPUS), Primary Care (P Care), and Bridging System applications

2. There are some items in SIMPUS and P Care that are not filled by the Puskesmas staff.

3. There are some data inputted into SIMPUS and $P$ care which are irelevant to the result of patients check up.

4. There is a security system installed on the computer and Puskesmas management information system and $\mathrm{P}$ care application.

5. There was another officer who did not have the right to access and use SIMPUS, P Care applications, and Bridging System.
6. The number of human resources, hardware, and information systems is not in accordance with the needs

7. The officers still repeatedly input the data in SIMPUS and Primary Care applications.

8. The patients who complain due to the long time service and the wait line at Puskesmas.

\section{REFERENCE
Adisasmito W (2010). Sistem Kesehatan. Jakarta: PT Raja Grafindo Persada.}

Arikunto S, Jafar CSA (2008).Evaluasi Program Pendidikan. Jakarta: Bumi Aksara

Azwar A (2010). Pengantar Adnministrasi Kesehatan. Tangerang: Binarupa Aksara.

Azwar S (2014). Metode Penelitian. Yogyakarta: Pustaka Pelajar.

Bachri BS (2010). Meyakinkan Validitas Data Melalui Triangulasi pada Penelitian Kualitatif. Surabaya: Universitas Negeri Surabaya.

Bata YW et al.(2013). Hubungan kualitas Pelayanan Kesehatan Dengan Kepuasan Pasien Penguna Akses Sosial Pada Pelayanan Rawat Inap Di RSUD Lakipadada Kabupaten Tana Toraja.

Budi SC (2011). Manajemen Unit Kerja Rekam Medis. Jakarta: Quantum Sinergis Media.

Cahyaningrum N (2015). Analisis Pelaksanaan Sistem Informasi Manajemen Puskesmas (SIMPUS) di UPTD Puskesmas Penumping Kota Surakarta.Surakarta: Apikes Citra Medika Surakarta.

Creswell JW (2015). Penelitian Kualitatif \& Desain Riset.Yogyakarta: Pustaka Pelajar.

Depkes RI (2006). Pedoman Penyelenggaraan dan prosedur Rekam Medis 
Journal of Health Policy and Management (2017), 2(2): 157-164

https://doi.org/10.26911/thejhpm.2017.02.02.07

Rumah Sakit di Indonesia. Jakarta: Direktorat Jenderal Pelayanan Medik. Depkes RI (2009). Sistem Kesehatan Nasional. Jakarta: Direktorat Jenderal Pelayanan Medik.

Djaelani AR (2013). Teknik Pengumpulan Data dalam Penelitian Kualitatif. Semarang.

Faizah N, Santoso PI (2015).Implementasi Integrasi Data Sistem Informasi Manajemen Puskesmas (SIMPUS) ke Sistem Informasi Dinas Kesehatan Kabupaten Gunung Kidul (SISDINKESGK). Yogyakarta: UGM.

Gavinov IT, Soemantri JFN(2016). Sistem Informasi Kesehatan. Yogyakarta: Nuha Medika.

Hatta G (2013). Pedoman Manajemen Informasi Kesehatan di Sarana Pelayanan Kesehatan. Jakarta.

Jogiyanto HM (2005). Penegnalan Komputer. ANDI. Yogyakarta.

Krishnan A, et al. (2010). Evaluation of computerized health management information system for primary health care in rural India. BMC health services research, 10: 310. doi: 10.1186/1472-6963-10-310.

Kristanto A (2007). Perancangan Sistem Informasi Dan Aplikasinya. Andri Kristanto. Yogyakarta.

Loudon KC (2007). Sistem Informasi Manajemen, Perusahaan Digital. Jane P. Loudon.

Menkes RI (2011). Peraturan Menteri Kesehatan Republik Indonesia No.1171/MENKES/PER/III/2011 Tentang Sistem Informasi Rumah Sakit.Jakarta : Depkes RI.

Menkes RI (2013). Peraturan Menteri Kesehatan Republik Indonesia Nomor 71 tahun 2013 tentang Pelayanan Kesehatan pada Jaminan Kesehatan Nasional. Jakarta.
(2014). Jaminan Kesehatan Nasional. Jakarta.

(2014). Peraturan Menteri Kesehatan Republik Indonesia Nomor 75 tahun 2014 tentang Puskesmas. Jakart.

(2015). Permenkes RI No 46 Tahun 2015 tentang akreditasi puskesmas, klinik pratama, tempat praktik mandiri dokter, dan tempat praktik mandiri dokter gigi. Jakarta.

(2016). Peraturan Menteri Kesehatan Republik Indonesia Nomor 44 Tahun 2016 Tentang Pedoman Manajemen Puskesmas. Jakarta.

(2017). Buku Pegangan Sosialisasi Jaminan Kesehatan Nasional (JKN) dalam Sistem Jaminan Sosial Nasional. Jakarta.

Mishra et al. (2012). Determinants of Health Management Information Systems Performance: Lesson from a District Level Assesment. Journal BMC. India.

Moleong LJ (2010). Metodologi Penelitian Kualitatif. Bandung: Remaja Rosda Karya.

Nilawati LN (2015).Penerapan Sistem Informasi Manajemen Puskesmas (SIMPUS) Berbasi Web di Puskesmas Pajang Surakarta. Surakarta. Universitas Muhammadiyah Surakarta.

Nugroho E (2008). Sistem Informasi Manajemen. Andi. Yoyakarta.

Nyamtema AS (2010). Bridging the Gaps in the Health Management Information System in the Context of a Changing Health Sector. Journal BMC Medical Informatics and Decision Making.

Prasetyowati A (2016). Analisis Integrasi Sistem Informasi Manajemen Puskesmas dan SIKDA Generik dengan Metode PRISM. Semarang.

Ramdhani AM (2014).Sistem Informasi Manajemen.Pustaka Setia. Bandung. 
Sedarmayanti (2014). Manajemen Strategi. Refika Aditama. Bandung.

Sutabri T (2012). Analisis Sistem Informasi. Andi. Yogyakarta.

Taufiq R (2013). Sistem Informasi Manajemen. Konsep Dasar, Analisis dan Metode Pengembangan. Yogyakarta: Graha Ilmu.

Undang-Undang Dasar Negara Republik Indonesia Tahun 1945.

Undang-Undang Republik Indonesia Nomor 36 tahun 2009 tentang keseha$\tan$.

Peraturan Menteri Kesehatan Republik Indonesia Nomor 27 Tahun 2014 Tentang Petunjuk Teknis Sistem Indonesian Case Base Groups (INA-CBGs) dengan, 7(256), pp. 2-13. Available at: http://publikasi.dinus.ac.id/index.php/fiki2013/article/view/508\%5 Cnhttp://jurnalkesmas.ui.ac.id/index. $\mathrm{php} / \mathrm{kesmas} /$ article/view/2/4.

Wariyanti AS, Suryono A, Indarto D (2016). Evaluation of the Management Information System at the Primary Health Care in the National Health Insurance. Journal Health Policy and management, 53-60.

Wibisono, Munawaroh (2012). Sistem Informasi Manajemen Puskesmas (SIMPUSKESMAS) berbasi Cloud Computing. Semarang: Universitas Stikubank. 